\title{
Cloning and Identification of Differentially Expressed Genes Induced by Fungal Infection from Silkworm, Bombyx mori
}

\author{
Jin-Sung Lee ${ }^{1,2 *}$, Su-young Hong ${ }^{1}$ and Ki Hwa Lee ${ }^{3}$ \\ ${ }^{1}$ Research Institute of Nareabio Tech Inc., 300, Cheoncheon-dong, Jangan-gu, Suwon, Kyunggi-do, 440-746 Korea \\ ${ }^{2}$ Department of Genetic Engineering, SungKyunKwan Univ., 300, Cheoncheon-dong, Jangan-gu, Suwon, Kyunggi-do, 440-746 Korea \\ ${ }^{3}$ Department of Alternative Medicine, Kyonggi Univ., 71, Chungjeongno 2-ga Seodaemun-gu, Seoul, 120-702 Korea
}

Received March 15, 2010 /Accepted April 23, 2010

\begin{abstract}
We tried to identify differentially expressed genes (DEGs) from a silkworm, Bombyx mori, involved in fungal (Aspergillus niger) infection. A total RNA purified from fungal-induced and normal B. mori $\left(5^{\text {th }}\right.$ instar larvae) was used for the cDNA synthesis. Differentially expressed genes were screened by annealing control primer (ACP)-based PCR technique. Comparing the gene expression profiles between fungal infection and control silkworm, we detected 10 genes that were differentially expressed in fungal induction and performed molecular cloning and nucleotide sequencing of the 10 genes. We confirmed the expression patterns of 3 DEGs by RT-PCR. The 3 DEGs over-expressed in fungal infection were identified as lysozyme, enbocin and an unknown gene. They were first identified to be genes induced by fungal infection. Although the detailed functions of 3 genes and their products remain to be determined, the genes will provide insight into the molecular mechanisms of insect-immune systems induced by fungal infection.
\end{abstract}

Key words : Silkworm, fungal infection, Aspergillus niger, DEG, RT-PCR

\section{서 론}

곤충은 병원체의 침입에 대한 혈 림프의 유도 방어 수단으 로 항 세균성 펩타이드를 생산하여 적극적 면역반응을 수행한 다[4]. Boman 등[2]이 처음으로 Hyalophora cecropia에서 cecropin, sttacin 및 lysozyme등의 항 세균성 단백질을 분리한 이 후, 곤충을 포함한 여러 동물에서 수 많은 항 세균성 단백질이 분리되고 있다. 지금까지 분리된 항 세균성 단백질은 분자량 이 작은 펩타이드 형태로서 숙주 특이성을 가지며 면역원의 종류, 양 그리고 감염 경과 시간에 따른 항 세균 활성이 서로 다르게 나타난다고 보고되고 있다[12].

H. cecropia에서 처음으로 분리된 cecropin은 $4 \mathrm{kDa}$ 의 항 세균성 펩타이드로서 7종이 보고되고 있는데 이중에서 주로 그람 양성 및 음성 세균에 활성을 갖는 cecropin A, B 및 D 형태가 잘 알려져 있다[18]. 한편, Schmidt 등이 H. cecropia에 서 발견한 hemoline은 면역반응시 면역원을 인지하여 혈 림프 에 존재하는 단백질과 면역원의 안정화를 위한 복합체 형성에 관여하여 초기 단계의 면역과정에 관여하는 항 세균 단백질로 알려져 있다[19]. Hultmark 등[10]이 발견한 attacin은 cecropin계의 항세균 단백질 보다 큰 분자량을 갖는 그람 음성 세균 에 특이적인 항 세균 활성을 나타낸다. 또한, 대부분의 인시목 곤충에서 발견되는 내재적 항 세균 단백질 중에서 lysozyme

*Corresponding author

Tel : +82-31-299-4852, Fax : +82-31-299-4853

E-mail : lejis@daum.net
은 cecropin이 작용한 후, 세균의 세포벽 성분을 가수분해하는 것이 주요 기능으로 다른 항 세균성 펩타이드와 달리 발현 수준이 수일 동안 유지되는 특성을 갖는다[17].

한편, 현재까지 곤충에서 분리, 보고된 항 세균성 단백질로 는 defensin, moricin, manduca $\mathrm{D}$, diptercin $\mathrm{A}$, abaecin, 등이 보고되고 있지만[1,3,5-7,9,11], 이러한 항 세균 단백질은 그람 음성 및 양성세균에 특이적인 것으로 진균 특이적인 단백질, 즉 항 진균성 단백질의 발견은 거의 보고되고 있지 않다. 따라 서 본 연구는 annealing control primer (ACP)-based PCR 기 술[13]을 이용하여 누에에 Aspergillus niger를 감염 시켜서 유 도 발현되는 항진균성 단백질을 암호화하는 유전자의 클로닝 과 동정을 목적으로 수행되었다.

\section{재료 및 방법}

\section{면역 유도}

본 연구에 이용된 누에는 표준 사육기준에 따라서 사육된 누에를 농촌진흥청 농업과학원으로부터 분양 받아 A. niger (KCCM 6014)의 감염을 위한 기주 곤충으로 사용하였다. 면역 원인 A. niger 는 potato dextrose agar 배지(Himedia, India)에 서 순수분리 하여 5 령기 누에 유충의 체강에 약 $6 \times 10^{8}$ colony per unit로 주사하여 면역반응을 유도시킨 뒤 6시간이 경과한 후에 $-70^{\circ} \mathrm{C}$ 에 냉동 보관하여 RNA 추출용 시료로 사용하였다. 


\section{Total RNA 분리 및 추출}

Altas $^{\mathrm{TM}}$ total RNA kit (Clontech, USA)을 일부 변형하여 A. niger에 감염된 5령기 누에 유충으로부터 total RNA를 분리 하였다. 우선 A. niger로 감염시킨 누에 및 대조군인 비유도 누에 유충을 액체질소로 급속 냉동시켜 유발에 균질화 한 다 음, $12.5 \mathrm{ml}$ 의 변성용액(4 M guanidine isothiocyanatem $5 \mathrm{mM}$ EDTA, $1 \%$ B-mercaptoethanol, $25 \mathrm{mM}$ sodium acetate)을 첨 가하였다. 얼음에 5 분간 방치하고 여기에 시료 중량과 동량의 phenol과 chloroform을 넣고 $12,000 \times g$ 로 원심분리하여 RNA 가 포함된 상층액을 새로운 튜브에 옮겼다. 이 과정을 1회 더 반복한 다음 $-20^{\circ} \mathrm{C}$ 의 isopropanol을 동량의 비율로 넣고 다시 $12,000 \mathrm{xg}$ 로 원심분리하여 RNA침전물을 얻었다. 마지막으로 $80 \%$ ethanol로 RNA pellet을 2회 세척하고 실온에서 건조하 여 total RNA를 분리, 추출하였다.

\section{CDNA 합성}

분리된 total RNA를 역전사 반응을 통해서 $1^{\mathrm{st}} \mathrm{cDNA}$ 를 합 성하였다. 역전사 반응은 $3 \mathrm{ug}$ 의 total RNA, $4 \mathrm{ul}$ 의 $5 \mathrm{x}$ reaction buffer (Promega, USA), 5ul의 dNTPs (각 $2 \mathrm{mM}$ ), $2 \mathrm{ul}$ 의 10 uM dT-ACP1 primer (5'-CGTGAATGCTGCGACTACGAT IIIII(T) ${ }_{18}-3$ ', Seegene, Korea), RNase inhibitor (40 U/ul, Promega, USA), 1ul의 molony murine leukemia virus reverse transcriptase (200 U/ul, Promega, USA)가 함유된 20 $\mathrm{ul}$ 용액을 $42^{\circ} \mathrm{C}$ 에서 2 시간 동안 반응시켜 $1^{\mathrm{st}} \mathrm{cDNA}$ 를 합성하 였다. 합성된 $\mathrm{cDNA}$ 는 $100 \mathrm{ul}$ 의 멸균 증류수에 녹여 $-20^{\circ} \mathrm{C}$ 에 보관하였다.

\section{PCR-based differential display}

GeneFishing $^{\mathrm{TM}}$ DEG kit (Seegene, Korea)를 사용하여 A. niger에 의해서 유도되는 누에의 발현 유전자를 $\mathrm{ACP}$ 기술에 기 초로 한 PCR-based differential display법에 의해 선별하였다. 우선 약 $50 \mathrm{ng}(3 \sim 5 \mathrm{ul})$ 으로 희석된 $1^{\text {st }}$ strand cDNA, $1 \mathrm{ul}$ 의 dT-ACP2 $(10 \mathrm{uM}), 1 \mathrm{ul}$ 의 $10 \mathrm{uM}$ arbitrary $\mathrm{ACP}, 10 \mathrm{ul}$ 의 $2 \mathrm{X}$ master mix가 포함된 최종 $20 \mathrm{ul}$ 의 용액을 $95^{\circ} \mathrm{C}$ 에서 1 분, $50^{\circ} \mathrm{C}$ 에서 3 분, $72^{\circ} \mathrm{C}$ 에서 1 분 동안 반응하여 double-strand cDNA 를 합성하였다. 다음 단계로 $94^{\circ} \mathrm{C}$ 에서 30 초, $65^{\circ} \mathrm{C}$ 에서 30 초, 72 도에서 1 분을 1 회로 하여 총 40 회 반복한 후, 최종적으로 증폭된 PCR 산물은 ethidium bromide $(10 \mathrm{ug} / \mathrm{ml})$ 가 함유된 $2 \%$ 의 agarose gel에서 분리, 확인하였다.

\section{Cloning 및 nucleotide sequencing}

Agarose gel 전기영동에 의해서 차별적 발현이 확인된 밴드 들은 Core-One ${ }^{\mathrm{TM}}$ Gel elution kit (CorebioSystems, Korea)를 사용하여 분리, 추출한 다음, $94^{\circ} \mathrm{C}$ 에서 30 초, $65^{\circ} \mathrm{C}$ 에서 30 초, $72^{\circ} \mathrm{C}$ 에서 1 분을 1 회로 하여 총 40 회 반복하였다. 마지막으로 $72^{\circ} \mathrm{C}$ 에서 5 분간PCR 반응을 1 회 더 실시한 후, TOPO TA vector system (Invitrogen, USA)를 사용하여 클로닝하였다. 이후 X-gal/IPTG를 이용하여 재조합된 대장균을 순수 분리하였다.
Table 1. Arbitrary primers for the differential-display PCR used from this study

\begin{tabular}{ll}
\hline Primers & \multicolumn{1}{c}{ Sequences } \\
\hline dT-ACP01 CTGTGAATGCTGCGACTACGATIIII(T) ${ }_{18}$ \\
dT-ACP02 CTGTGAATGCTGCGACTACGATIIII(T) ${ }_{15}$ \\
ACP 01 & GTCTACCAGGCATTCGCTTCATIIIIIGCCATCGACC \\
ACP 02 & GTCTACCAGGCATTCGCTTCATIIIIAGGCGATGCC \\
ACP 03 & GTCTACCAGGCATTCGCTTCATIIIIICCGGAGGATG \\
ACP 04 & GTCTACCAGGCATTCGCTTCATIIIIIGCTGCTCGCG \\
ACP 05 & GTCTACCAGGCATTCGCTTCATIIIIIAGTGCGCTCG \\
ACP0 6 & GTCTACCAGGCATTCGCTTCATIIIIGGCCACATCG \\
ACP 07 & GTCTACCAGGCATTCGCTTCATIIIIICTGCGGATCG \\
ACP 08 & GTCTACCAGGCATTCGCTTCATIIIIIGGTCACGGAG \\
ACP 09 & GTCTACCAGGCATTCGCTTCATIIIIIGATGCCGCTG \\
ACP 10 & GTCTACCAGGCATTCGCTTCATIIIITGGTCGTGCC \\
ACP 11 & GTCTACCAGGCATTCGCTTCATIIIIICTGCAGGACC \\
ACP 12 & GTCTACCAGGCATTCGCTTCATIIIIIACCGTGGACG \\
ACP 13 & GTCTACCAGGCATTCGCTTCATIIIIIGCTTCACCGC \\
ACP 14 & GTCTACCAGGCATTCGCTTCATIIIIIGCAAGTCGGC \\
ACP 15 & GTCTACCAGGCATTCGCTTCATIIIIICCACCGTGTG \\
ACP 16 & GTCTACCAGGCATTCGCTTCATIIIIIGTCGACGGTG \\
ACP 17 & GTCTACCAGGCATTCGCTTCATIIIIICAAGCCCACG \\
ACP 18 & GTCTACCAGGCATTCGCTTCATIIIIICGGAGCATCC \\
ACP 19 & GTCTACCAGGCATTCGCTTCATIIIIICTCTGCGAGC \\
ACP 20 & GTCTACCAGGCATTCGCTTCATIIIIIGACGTTGGCG \\
\hline
\end{tabular}

Core-One $^{\mathrm{TM}}$ Miniprep kit (CorebioSystems, Korea)를 사용하 여 분리한 대장균으로부터 plasmid DNA를 추출한 다음, $\mathrm{ABI}$ PRISM $^{\mathrm{TM}} 3100$ Genetic Analyzer (Applied Biosystems, USA) 를 이용하여 염기서열을 결정하였다. 이후 NCBI의 BLASTX 상동성 검색을 통해서 차별적으로 발현되는 유전자를 동정하 였다.

\section{Reverse transcriptase (RT)-PCR}

발현 차이를 보이는 유전자들은 해당하는 primer를 사용하 여 reverse transcriptase-PCR(RT-PCR) 방법을 통해서 A. niger 감염에 의해서 유도되어 발현되는지를 최종 확인하였다. $1^{\text {st }}$ strand cDNA를 $\beta$-actin 유전자(Forward primer: 5' TGACGGGGTCACCCACACTGTGC, Reverse primer: 5'CTAGAAGCATTTGCGGTGGACGGATGGAGGG)를 이용 하여 표준화시킨 후 주형으로 사용하였다. 약 $50 \mathrm{ng}$ 의 희석시 킨 $1^{\text {st }} \mathrm{cDNA}$, 각 $1 \mathrm{ul}(10 \mathrm{uM})$ 의 5', $3^{\prime}$ primer $($ 각 $10 \mathrm{uM})$ 그리고 $10 \mathrm{ul}$ 의 2X master mix (Seegene, Korea)가 포함된 20ul의 반 응액을 상기에서와 같은 PCR 조건으로 증폭하였다. 증폭된 PCR 반응액은 $2 \%$ 의 agarose gel 전기영동법으로 분리, 확인 하였다.

\section{결과 및 고찰}

ACP-based PCR 방법을 이용한 GenFishing ${ }^{\mathrm{TM}}$ DEG 
(Differentially Expressed Gene) 방법을 통해서 A. niger에 의 해서 유도되거나 억제되는 10 개의 밴드를 확인 할 수 있었다 (Fig. 1). Agarose gel에서 확인된 9개의 밴드(DEG 1, 2, 3, 5, $6,7,8,9$ 및 10)는 A. niger의 감염에 의해서 유도 발현되는 유전자이며 DEG 4는 A. niger의 감염에 의해서 발현이 억제되 는 유전자로 확인되었다. 이들 밴드들을 agarose로부터 분리 하여 클로닝을 하고 염기서열을 분석한 다음, $\mathrm{NCBI}$ 의 BLASTX 상동성 검색을 수행한 결과, DEG 1, 2, 3, 4, 8 등 5 개의 유전자 정보를 확인하였다(Table 2). 하지만 DEG 5, 6, 7,9 와 10 은 GenBank 상의 어떠한 유전자들과 유의한 상동성 을 보여 주지 않는 현재까지 보고되지 않은 유전자들이었다. BLASTX 상동성 분석으로 A. niger의 감염에 의해서 발현이 증가되는 유전자는 lysozyme (DEG 1), enbocin (DEG 2), lysosomal thiol reductase IP30 (DEG 3) 및 high basic serine protease $(\mathrm{DEG} 8)$ 등이 동정되었고 발현이 감소하는 $\mathrm{DEG} 4$ 는 internal transcribed spacer 1과 유의한 상동성(4e-87)을 보이 는 것으로 나타났다.

1 차 스크리닝을 통해서 A. niger 감염에 의해서 발현이 증가 혹은 감소되는 상기 10개 DEGs에대해서 RT-PCR을 수행하여 A. niger에 의한 유도 발현을 검증하였다. 여기에 사용된 primer는 Table 3과 같다. Internal control 유전자로 사용한 $\beta$ -actin의 발현량을 기준으로 하여 A. niger 처리 누에와 미처리 누에 사이의 RT-PCR 산물의 감도를 비교해서 보면, DEG 1
Table 3. Nucleotide sequences of DEGs-specific primers for the RT-PCR

\begin{tabular}{|c|c|c|}
\hline $\begin{array}{l}\text { Clone } \\
\text { No. }\end{array}$ & $\begin{array}{c}\text { Annealing } \\
\text { Temperature }\end{array}$ & Primer sequence $\left(5^{\prime}-3^{\prime}\right)$ \\
\hline \multirow{2}{*}{ DEG 01} & \multirow{2}{*}{$55^{\circ} \mathrm{C}$} & F : ACGGCAATAGGAATGTTTTA \\
\hline & & R : TTTCAAGGCCTGATTGTACT \\
\hline \multirow{2}{*}{ DEG 02} & \multirow{2}{*}{$50^{\circ} \mathrm{C}$} & F : GCTCGCGTTCACAAATTGCT \\
\hline & & R : ATTAATATCTCCAAAAGGCA \\
\hline \multirow{2}{*}{ DEG 03} & \multirow{2}{*}{$55^{\circ} \mathrm{C}$} & F : GTACGGTGATAAAACGGATG \\
\hline & & R : CATTTTACGAGCAGATCGAC \\
\hline \multirow{2}{*}{ DEG 04} & \multirow{2}{*}{$55^{\circ} \mathrm{C}$} & F : CTGTGAATGCTGCGACTAC \\
\hline & & R : TTTTCTTAACGTGTGTGTGC \\
\hline \multirow{2}{*}{ DEG 05} & \multirow{2}{*}{$63^{\circ} \mathrm{C}$} & F : AACCGCGTATTCGTACTGTCC \\
\hline & & R : TTTTAAGTTGGCAAGCGTCC \\
\hline \multirow{2}{*}{ DEG 06} & \multirow{2}{*}{$55^{\circ} \mathrm{C}$} & F : TTTGAGATTTGCCATGTACGT \\
\hline & & R : AGCAGATAGAGCACATGAATT \\
\hline \multirow{2}{*}{ DEG 07} & \multirow{2}{*}{$63^{\circ} \mathrm{C}$} & F : GGCCAGACTTCCAAGTACGA \\
\hline & & R : CGGCCTCCTCTTCTTCTTCT \\
\hline \multirow{2}{*}{ DEG 08} & \multirow{2}{*}{$55^{\circ} \mathrm{C}$} & F : GCACAGCTAACATCTTCTCC \\
\hline & & R : CAATGATCACATTGTTTCCA \\
\hline \multirow{2}{*}{ DEG 09} & \multirow{2}{*}{$55^{\circ} \mathrm{C}$} & F : CTGTGAATGCTGCGACTAC \\
\hline & & R : ACGCAGTGAATCTTTCTGAT \\
\hline \multirow{2}{*}{ DEG 10} & \multirow{2}{*}{$63^{\circ} \mathrm{C}$} & F : ATGCAGCTATCATTCCCCAG \\
\hline & & R : AGAGGGTATGATGGGGGTTC \\
\hline
\end{tabular}

F: Forward, R: reverse

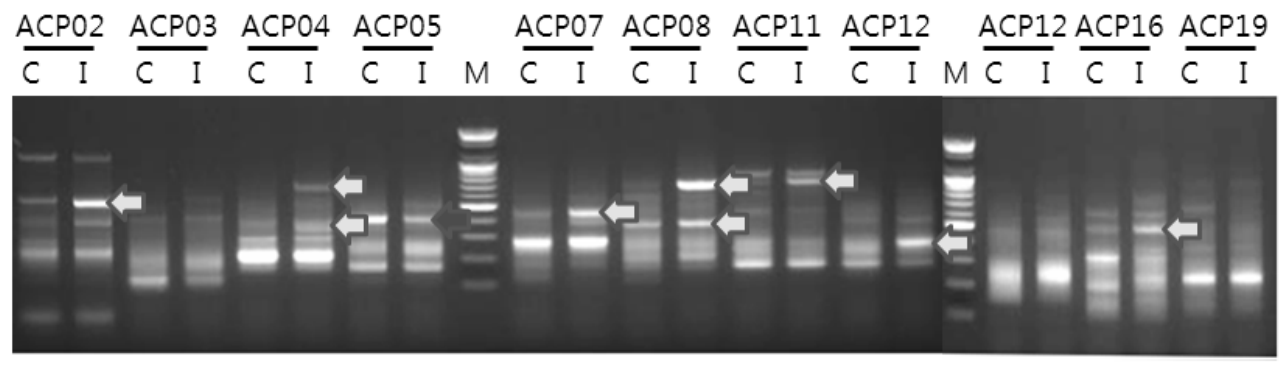

Fig. 1. Agarose gel electrophoresis of genes induced by infection of A. niger. C: normal, I: A. niger infection, M: 100 bp DNA size marker. The arrows indicate up-and down-regulated genes by A. niger infection.

Table 2. Differentially expressed genes from silkworm by infection of A. niger

\begin{tabular}{ccc}
\hline Clone No. & Homology & Amino acids similarity (E-value) \\
\hline DEG 01 & lysozyme & $476 / 485(0.0)$ \\
DEG 01 & Lysozyme & $476 / 485(0.0)$ \\
DEG 02 & Enbocin & $139 / 139(5 \mathrm{e}-71)$ \\
DEG 03 & Lysosomal thiol reductase IP30 & $277 / 283(3 \mathrm{e}-140)$ \\
DEG 04 & Internal transcribed spacer 1 & $168 / 169(4 \mathrm{e}-87)$ \\
DEG 05 & Unknown & \\
DEG 06 & Unknown & \\
DEG 07 & Unknown & $554 / 596(0.0)$ \\
DEG 08 & High basic serine protease & \\
DEG 09 & Unknown & \\
DEG 10 & Unknown & \\
\hline
\end{tabular}


(lysozyme), DEG 2 (enbocin) 및 DEG 9 (unknown gene) 등 3 개의 유전자가 A. niger의 감염에 의해서 누에에서 발현이 크게 증가하는 유전자로 최종 확인되었다(Fig. 2). 하지만, DEG 3, 5, 6, 7, 8 및 10 등, 6개의 유전자는 A. niger에 의한 유도발현이 미 처리군에 비해서 약한 발현 증가만을 보여주었 다. 또한, A. niger에 의해 발현이 억제되는 DEG 4 (internal transcribed spacer 1)의 RT-PCR 결과는 미약하게 발현이 감 소되는 것으로 확인되었다(Fig. 2).

본 연구는 PCR법을 이용하여 누에에 A. niger을 감염시킬 때 유도 발현되는 유전자를 동정하여 지금까지 보고되지 않은 항 진균성 단백질 또는 이와 관련한 유전자를 탐색하는 것이 다. 유전자의 유도성 발현 차이를 확인하는 방법으로 최근에 많이 사용되는 DNA chip은 시험의 비용과 통계적 분석등 아 직까지 연구에 적용하기 위한 접근성이 떨어지는 반면에[20] $\mathrm{PCR}$ 을 응용한 방법은 발현의 차이를 직접 agarose gel에서 직접 비교할 수 있기 때문에 기존의 방법이 갖는 낮은 재현성 과 높은 위양성율을 극복할 수 있는 장점이 있어 현재도 다양 한 방법으로 응용되는 기술이다[8,21,22]. 따라서 본 연구는 $\mathrm{PCR}$ 기법 중에서 Seegene사의 ACP 기술을 기초로 한 GeneFishing DEG Kit를 이용한 Differential Display-PCR법 을 통해서 A. niger에 의해서 유도 발현되는 누에의 유전자를 분리, 동정하고자 하였다.

본 연구로부터 분리 확인된 DEG 1은 곤충의 혈림프에 존재 하는 11 12 kDa의 분자량을 갖는 항 세균성 펩타이드인 lysozyme으로 $H$. cecropia의 lysozyme과 높은 상동성(E-value: 5e-83)을 보였다. Jolles 등[14]은 H. cecropia에서 분리한 lysozyme이 120 개의 아미노산으로 구성되며 곤충의 다양한 체액 성 면역기구를 구성하도록 attacin과 cecropin과 함께 상호 보 안 작용을 한다고 보고하고 있다. 따라서 누에의 lysozyme이 A. niger에 의해서 유도 발현되는 것으로 보아 lysozyme이 세

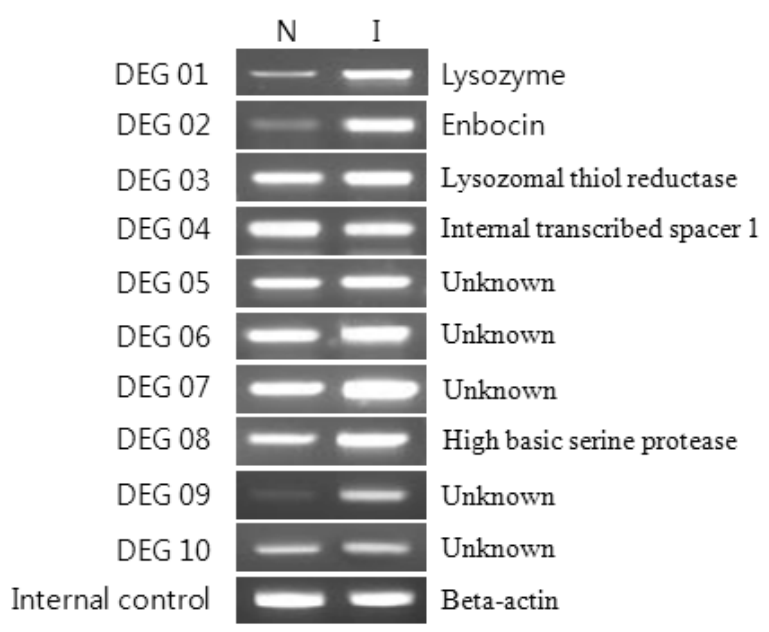

Fig. 2. RT-PCR profiles of 10 DEGs. $\beta$-actin gene was used as a house-keeping gene for a internal control. N: normal, I: A. niger infection.
균에 의한 체액성 면역 뿐 아니라 곰팡이 감염에 대한 체액성 면역 기전에도 중요한 역할을 하는 것으로 추정할 수 있었다. 또한, A. niger에 의해서 과 발현이 유도되는 enbocin (DEG 2)은 cecropin family에 속하는 항 세균성 펩타이드로서 cecropin이 그람 음성 세균에 강한 활성이 있는데 반해 enbocin은 그람 양성 균에 강한 활성을 갖는 것으로 알려져 있다[16]. 하 지만, enbocin이 A. niger에 의해서 유도되어 과발현되며 항 진균 활성이 있다는 보고[15]는 현재까지 없는 바, 향후 enbocin에 대한 in vivo 항 진균 활성에 대한 검증이 필요할 것으로 생각한다. 마지막으로 RT-PCR을 통해서 A. niger에 의한 유도 발현이 가장 높은 DEG 9는 현재까지 보고되지 않는 유전자로 앞으로 이 유전자에 대한 기능 연구를 통해 새로운 항 진균 성 단백질의 발견 가능성을 기대해 본다.

이상의 연구 결과로부터 A. niger의 감염으로 유도 발현되 는 누에의 유전자들을 미 처리구를 대조군으로 하여 항 진균 활성 기전과 관련된 몇 개의 유전자들을 분리할 수 있었다. 특히 기존의 유전자와 상동성을 보이지 않는 DEG 9가 RT-PCR을 통해서 잠정적으로 곰팡이 균에 의해서 과 발현되 는 유전자라는 것을 검증됨으로써 앞으로 이 유전자의 다양한 기능연구가 필요할 것으로 생각된다.

\section{References}

1. Alcouloumre, M. S., M. A. Ghannoum, A. S. Ibrahim, M. E. Sested, and J. E. Edwards. 1993. Fungicidal properties of defensin NP-1 and activity against Cryotococcus neoformans in vitro. Antimicrobial Agents and Chemotherapy 37, 2628-2632.

2. Boman, H. G., I. Faye, G. H. Gudmundsson, J. Y. Lee, and D. A. Lidholm. 1991. Cell free immunity in cecropia : A model system for antibacterial proteins. Eur. J. Biochem. 201, 23-31.

3. Bradbury, A. F. and D. G. Smyth. 1991. Peptide amidation. Tips Biochem. Sci. 16, 112-115.

4. Brehelin, M. and N. Boemare. 1988. Immune recognition in insects: conflicting effect of autologous plasma and serum. J. Compara. Physiol. Biochem. System. Environ. Physiol. 157, 759-764.

5. Casteels, P., C. Ampe, L. Riviere, J. V. Damme, C. Elicone, M. Fleming, F. Jacops, and F. Tempst. 1990. Isolation and Characterization of abaecin, a major antibacterial response peptide in the honeybee (Apis mellipera). Eur. J. Biochem. 187, 381-386.

6. Cociancich, S., A. Ghazi, C. Hetru, J. A. Hoffmann, and L. Leteliers. 1993. Insect defensin, an inducible antibacterial peptide forms voltage-dependent channels in Microccus luteus. J. Bio. Chem. 268, 19239-19245.

7. Cociancich, S., M. Goyffon, F. Bontms, P. Bulet, F. Bouet, A. Menez, and J. Hoffman. 1993. Purification and characterization of a scorpion defensin, a $4 \mathrm{kDa}$ antibacterial peptide presenting structural similarities with insect defencin and 
scorpion toxins. Biophy. Biochem. Res. Commun. 194, 17-22.

8. Cui, X. S., M. R. Shin, K. A. Lee, and N. H. Kim. 2005. Identification of differentially expressed genes in murine embryos at the blastcyst stage using annealing control primer system. Molecular Reproduction and development 70, 278-287.

9. Dimarcq, J. L., E. Keppi, B. Dunbar, J. Lambert, J. M. Reichhart, D. Hoffman, S. M. Rankine, J. E. Fothergil, and J. A. Hoffman. 1988. Purification and characterization of a family of novel inducible antibacterial proteins from immunized level of the dipteran Phormia terranovae and complete amino acid sequence of the predominant member, Diptericin A. Eur. J. Biochem. 171, 17-22.

10. Haltmark, D., A. Engstrom, K. Anderson, H. Steiner, H. Bennich, and H. G. Bomam. 1983. Attacins, a family of antibacterial proteins from Hyalophora cecropia. EMBO J. 2, 571-576.

11. Hara, S., and M. Yamakawa. 1995. Moricin, a novel antibacterial peptide, isolated from the silkworm, Bombyx mori. J. Biol. Chem. 270, 29923-29927.

12. Hoffman, J. A., F. C. Kafatos, and C. A. Janeway. 1999. Phylogenetic perspectives in innate immunity. Science 284, 1313-1318.

13. Hwang, I. T., Y. J. Kim, S. H. Kwak, Y. Y. Gu, and J. Y. Chun. 2003. Annealing control primer system for improving specificity of PCR amplification. Biotechniques 35, 1180-1184.

14. Jolles, P. and J. Jolles. 1984. What's new in lysozme research? Always a model system. Mole. Cell Biochem. 63,
165-189.

15. Kaneko, Y., S. Furukawa, H. Tanaka, and M. Yamakawa. 2007. Expression of antimicrobial peptide genes encoding enbocin and gloverin isoforms in the silkworm, Bombyx mori. Biosci. Biotechnol. Biochem. 71, 2233-2241.

16. Kim S. H., B. S. Park, E. Y. Yun, Y. H. Je, S. D. Woo, S. W. Kang, K. Y. Kim, and S. K. Kang. 1998. Cloning and expression of a novel gene encoding a new antibacterial peptide from silkworm, Bombyx mori. BBRC. 246, 388-392.

17. Mulnix, A. B. and P. E. Dunn. 1994. Structure and induction of a lysozyme gene from the tobacco hornworm, Manduca sexta. Insect Biochem. Mole. Biol. 24, 271-281.

18. Qu, X. M., H. L. Tang, and S. Hakan. 1989. The effect of cecropins B and D from the Chinese oak silkmoth(Antheraea pernyi) on liposomes. Biophys. Biochem. Acta. 21, 35-42.

19. Schmidt, O., I. Faye, I. Lindstrom-Dinnetz, and S. C. Sun. 1993. Specific immune recognition of insect hemoline. Develop. and Compara. Immunol. 17, 195-200.

20. Shalon, D. 1998. Gene expression microarrays: a new tool or genomic research. Pathol. Biol. 243, 107-109.

21. Yoon, S. J., H. M. Chung, and K. Y. Cha. 2005. Identification of differentially expressed gene expression in germinal vesicle vs metaphase II mouse oocytes by using annealing control primers. Fertility and Sterility 83, 1293-1296.

22. Yum, S. S., S. O. Woo, and E. S. Choi. 2005. Analysis of gene expression in benzopyrene-exposed Sebastes schlegeli using differential display polymerase chain reaction. Journal of Environmental Toxicology 20, 67-73.

\title{
초록 : 누에에서 곰팡이(Aspergillus niger) 감염에 의해 유도 발현되는 유전자의 클로닝과 동정
}

\author{
이진성 ${ }^{1,2 *} \cdot$ 홍수영 $^{1} \cdot$ 이기화 ${ }^{3}$ \\ ('주)나래바이오테크, ${ }^{2}$ 성균관대학교 유전공학과, ${ }^{3}$ 경기대학교 대체의학과)
}

본 연구는 곤충으로부터 새로운 항 진균 단백질을 발굴하기 하기 위한 목적으로 누에를 대상으로 Aspergillus niger의 감염을 유도하였을 때 발현되는 유전자의 특성을 분석한 것이다. Annealing control primer 법에 기초한 GeneFishing Kit를 사용하여 A. niger를 약 $6 \times 10^{8}$ colony per unit로 5령기 누에 유충의 체강에 감염시킨 후, 6 시 간 경과한 다음에 유도 발현되는 유전자(differentially expressed genes, DEGs)를 분석 한 결과, 10 개의 유도 발현 되는 유전자를 분리하였고 RT-PCR을 통해서 lysozyme, enbocin 그리고 한 개의 기능이 알려지지 않는 유전자 등 3개의 유전자가 A. niger의 감염에 의해서 유의하게 과 발현된다는 것을 검증하였다. 일반적으로 그람 음성 및 양성 세균의 감염에 의해 유도된다고 알려진 enbocin 유전자가 A. niger의 감염에서도 과 발현이 유도되는 본 연구의 결과는 앞으로 enbocin 유전자의 항 진균 활성 연구에 중요한 기초 자료로 활용될 수 있을 것이다. 